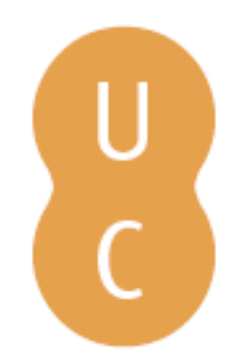

\title{
nommalina
}

\section{Plasticity of fire related traits of some obligate seeder species in different fire-prone areas of SE France: the goals and methodology used}

Autor(es): $\quad$ Romero, Bastien; Ganteaume, Anne

Publicado por: Imprensa da Universidade de Coimbra

URL

persistente: URI:http://hdl.handle.net/10316.2/44546

DOI: $\quad$ DOI:https://doi.org/10.14195/978-989-26-16-506_29

Accessed : $\quad$ 26-Apr-2023 09:47:49

A navegação consulta e descarregamento dos títulos inseridos nas Bibliotecas Digitais UC Digitalis, UC Pombalina e UC Impactum, pressupõem a aceitação plena e sem reservas dos Termos e Condições de Uso destas Bibliotecas Digitais, disponíveis em https://digitalis.uc.pt/pt-pt/termos.

Conforme exposto nos referidos Termos e Condições de Uso, o descarregamento de títulos de acesso restrito requer uma licença válida de autorização devendo o utilizador aceder ao(s) documento(s) a partir de um endereço de IP da instituição detentora da supramencionada licença.

Ao utilizador é apenas permitido o descarregamento para uso pessoal, pelo que o emprego do(s) título(s) descarregado(s) para outro fim, designadamente comercial, carece de autorização do respetivo autor ou editor da obra.

Na medida em que todas as obras da UC Digitalis se encontram protegidas pelo Código do Direito de Autor e Direitos Conexos e demais legislação aplicável, toda a cópia, parcial ou total, deste documento, nos casos em que é legalmente admitida, deverá conter ou fazer-se acompanhar por este aviso. 


\section{ADVANCES IN}

\section{FOREST FIRE RESEARCH}

\section{8}

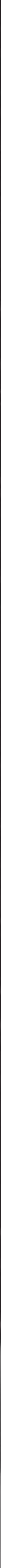




\title{
Plasticity of fire related traits of some obligate seeder species in different fire-prone areas of SE France: the goals and methodology used
}

\author{
Bastien Romero*, Anne Ganteaume \\ Irstea.3275 Route de Cezanne, 13100 Aix-en-Provence, France \{bastien.romero@irstea.fr*, \\ anne.ganteaume@irstea.fr\}
}

\begin{abstract}
Species having traits adapted to a given fire regime can be endangered when the fire regime changes if these traits do not vary at the same time, especially with the increase in fire recurrence following the global change. In this framework, an on-going $\mathrm{PhD}$ work studies plant fire-traits and flammability according to the fire regime to highlight a possible adaptation of these traits which would confer a better flammability when the fire recurrence increases to the resilient species Pinus halepensis and a better resistance to fire to the resistant species Pinus sylvestris. The study area encompasses two locations located on North-South gradient of the Provence area (SE France) to verify is the trend is the same within the biogeographical range of the species and at its boundaries. The current paper presents the goals of this work and methodology implemented to achieve them
\end{abstract}

Keywords: Fire Regime, Fire-related Traits, Plasticity, Flammability, Mediterranean Region, Climate Change

\section{Introduction}

Wildfires have been shaping landscapes in the Mediterranean regions for thousands years (Keeley et al. 2011) as climate conditions in these areas favour fire ignition and propagation, and most species have adapted because of this high selection pressure (Pausas \& Keeley 2009, Moreno \& Oechel 2012). However, for decades, the increase in temperature has led to an increase in fire activity all over the world (Westerling et al. 2006; Pausas 2004; Oliveira et al. 2012). At the global scale as at regional scale (i.e. Mediterranean basin), this trend is likely to be strengthened (Moritz et al. 2012; Pausas et al. 2004) leading to an increase in risks such as the forest fire risk. Moreover, changes in the boundaries of bio-climatic areas are expected, especially in the northern part of the French Mediterranean region and at higher elevation that should also lead to an increase in the fire risk towards the North. Some species could be impacted by this change, as, for instance, the European mountain trees that are unequally exposed to an increasing fire risk according to their niche flammability (Fréjaville 2015), or species present in several bio-climatic areas that are adapted to specific conditions, such as fire regimes (Bradshaw et al. 2011; Keeley et al. 2011; Pausas 2015).

Plant flammability is an important driver that plays a fundamental role in terrestrial ecosystems (Bond \& Keeley 2005). Fire-related traits enhancing flammability differ between species (Papió \& Trabaud 1991; Behm et al. 2004) and affect different components of flammability (Santana et al. 2011; Schwilk \& Caprio 2011); some plant communities are thus more likely to burn than others (Bond \& Van Wilgen 1996). Different adaptation strategies are used by species depending on the fire regime, inducing different fire-related traits. For low to medium intensity surface fires, these traits enable species to survive in case of fire (resistant species) in decreasing the fire impact (thick bark, selfpruning, and large height) and being less flammable (i.e. higher leaf or litter bulk density). On the 
contrary, resilient species have adapted to high intensity crown fires favouring their post fire regeneration capacity (developing functional traits such as serotiny) and thus enhancing their capability to burn (with structural and chemical traits such as high dead fuel retention i.e.no selfpruning, high contents of chemical compounds i.e. terpenes in leaves and litter, or a low fuel bulk density, etc.) that allow these species to create their own ecological niche according to Bond \& Midgley's "Born to Burn” hypothesis (1995).

Previous works on plant flammability in fire-prone ecosystems have mostly focused on differences between species, especially between different regeneration strategies (Cowan \& Ackerly 2010; SauraMas et al. 2010) and suggested different genetic mechanisms explaining the evolution of flammability (Kerr et al. 1999; Schwilk \& Kerr 2002). However, the functional traits such as resprouting, serotiny are adaptative in fire-prone environments even if the plants are more adapted to a fire regime than to the fire itself (Keeley et al. 2011) and their traits linked to flammability could vary with a change in the fire regime. However, few works, such as that of Pausas et al. (2012), studied the intraspecific variability and its relation to fire regime but these works generally focused on one type of fuel to assess flammability and on one geographical area (generally within the biogeographical range of the species studied). As stated by Keeley et al. (2011), species having traits adapted to a given fire regime can be endangered when the fire regime changes if these traits do not vary at the same time, especially with the increase of the fire recurrence following the global change, but also with the implementation, in some place, of recurrent prescribed burnings to control the fuel biomass. Identifying if there is a variation of the fire-related traits and of the flammability (and to what extent) according to the fire regime, within intraspecific populations of species will be necessary to predict ecosystem responses to on-going global change.

The aims of this on-going PhD work are (i) to compare the fire-related traits and fuel flammability in different populations sampled in areas submitted to different fire regimes (high fire regime vs low fire regime), in two geographical areas of SE France and (ii) to highlight possible micro-evolutional responses at the different fire regimes, looking for the traits heritability. The current paper focuses on the methodology used to achieve these goals.

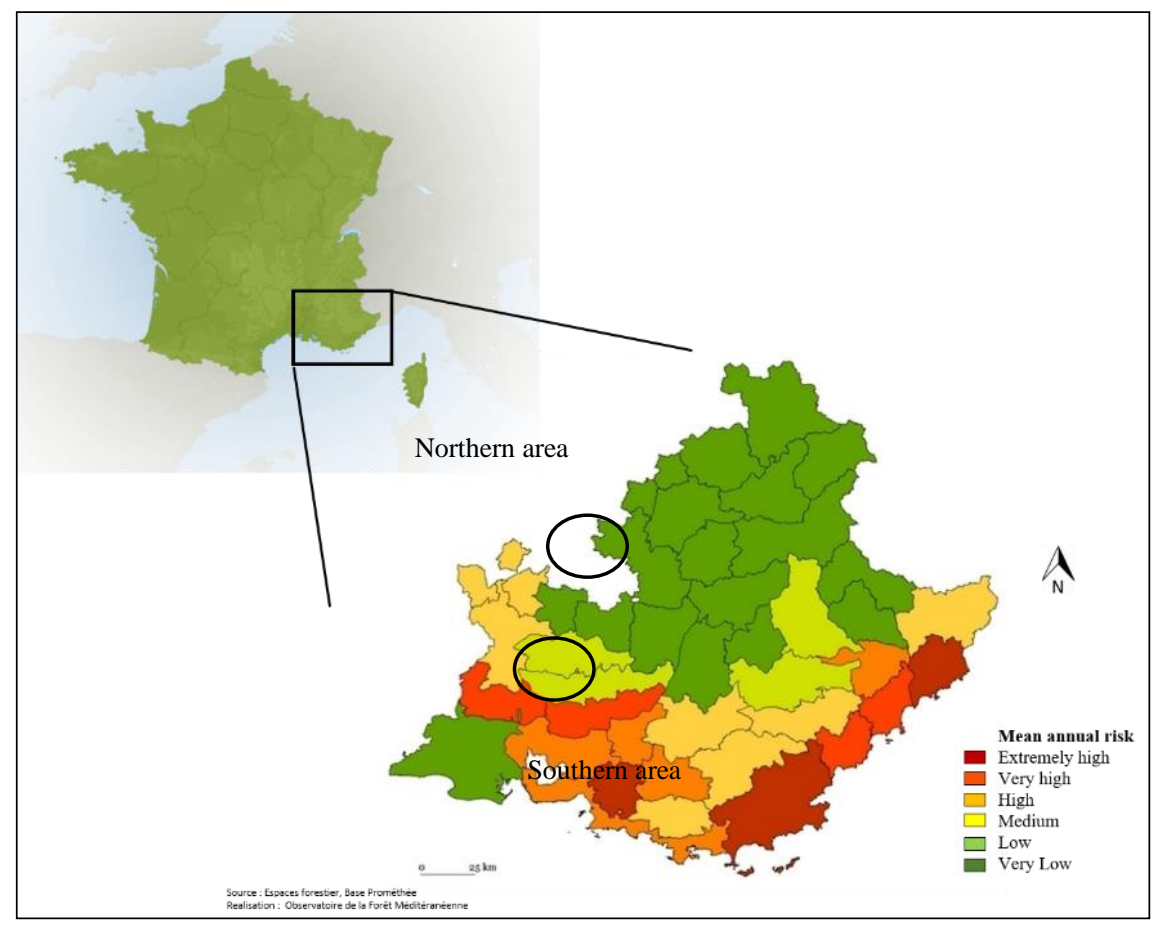

Figure 1 - Map of the fire risk in Provence, SE France (according to fire occurrence and burned area) and the two study areas. 


\section{Methodology}

\subsection{Study areas}

In France, the study areas are located in Provence (Southeastern France). This region is one of the most affected by wildfires (Forest Fires Database of Direction Départementale du Territoire, DDT) with a fire history recorded since 1960 and therefore presents a wide range of fire-prone ecosystems and provides a large gradient of bioclimatic conditions from Thermo-Mediterranean to OroMediterranean, acting on the fire risk. . The work is carried out in two different biogeographical areas, one located in the South of Provence where the fire regime is high and the other in the North of this region (regional natural park of Baronnies Provençales), where the fire frequency and intensity are less severe (Fig. 1), in order to show if the possible trends of adaptation remain the same when the species is sampled within its biogeographical range and at the boundaries of this range.

\subsection{Species studied}

As stated by Pausas et al. (2014), obligate seeders that are species that lack resprouting ability and for whom post-fire regeneration relies only on germination from the seed bank (Bond \& Van Wilgen 1996; Pausas et al. 2004), have shorter and no overlapping generations as well as higher population turnover than resprouters (Verdú et al. 2007). Thus, this species should be more sensitive to fire regime changes. In the current work, two obligate seeder species that present different adaptive strategies to fire, i) Pinus halepensis (resilient species) and ii) Pinus sylvestris (resistant species), are studied.

\subsubsection{The resilient species Pinus halepensis}

$P$. halepensis is a typically fire-resilient species adapted to high intensity crown fire regime and is dominant in the region, especially in its southern part and at low elevation. Post-fire $P$. halepensis strategies are based on sexual reproduction and seed development and are related to seed storage in long-closed cones that stay closed pending the arrival of a fire; the high temperature causing the opening of the cones and the seed release (Lamont et al. 1991; Tapias et al. 2004). This post fire regeneration depends totally upon this species' canopy-stored seed bank (Ne'eman et al. 2004), mechanism called serotiny. Serotiny and early flowering in Pinus halepensis reflect its resilient strategy in relation to fire as this character is advantageous to survive frequent crown fires and to attain successful post-fire recruitment (Tapias et al. 2004).

\subsubsection{The resistant species Pinus sylvestris}

Contrary to the previous pine species, Pinus sylvestris is more adapted to low/medium intensity surface fire regime (Agee 1998; Keeley 2012) and is present especially in the northern part of the region and at higher elevation. Non-serotinous pines, like Pinus sylvestris, once they are burned in an intense fire, are dependent for their recovery on seed dispersal from adjacent unburned patches. In the case of a light or moderate surface fires, trees are protected by their thick bark and because of the selfpruning of the dead branches, their canopy is not affected, allowing seed germination after fire (Retana et al. 2002). Late flowering and absence of serotinous cones in this pine species indicate that their natural forest did not evolve under frequent crown fires (Tapias et al 2004). Phylogenetic studies indicate a strong correlation between heights, self-pruning, and bark thickness in this pine species (Schwilk and Ackerly 2001).

\subsection{Sampling}

The main challenge of this work is to assess the intraspecific variations of the fire-related traits and flammability in pine populations submitted to different fire regimes avoiding, as much as possible, differences in environmental conditions. In order to measure the actual variations due to the fire regime, the populations of both species are sampled according to many environmental similarities (i.e. 
altitude, exposure, aspect, age of the trees, understorey floristic composition, past land use, etc. ; Fig. 2).

In order to sample the populations according to two different fire regimes, a map of the fire perimeters (fire size $>2$ ha) has been performed using the regional fire database of DDT and satellite images before and after each fire (Fig. 3).

For each species, three (in the North) to five populations are sampled in zones where fires have never occurred ( $\mathrm{NoFi}$ ) and three to five others in zones where several fires (one at least in the northern part of the study area which is less impacted by fires) occurred (HiFi) since the last 60 years.

In each area, climatic conditions of HiFi populations should be within the range of the conditions of NoFi populations, that is, there is no geographical segregation between HiFi and NoFi populations. Indeed, the sampling of different populations (of same age) of obligate seeder species must be carried out in a way that the differences of phenotypes observed between different populations are not related to environmental conditions, but are a result of the difference in fire regime (populations coming from old-field colonization for low fire regime vs populations coming from post-fire colonization for high fire regime).

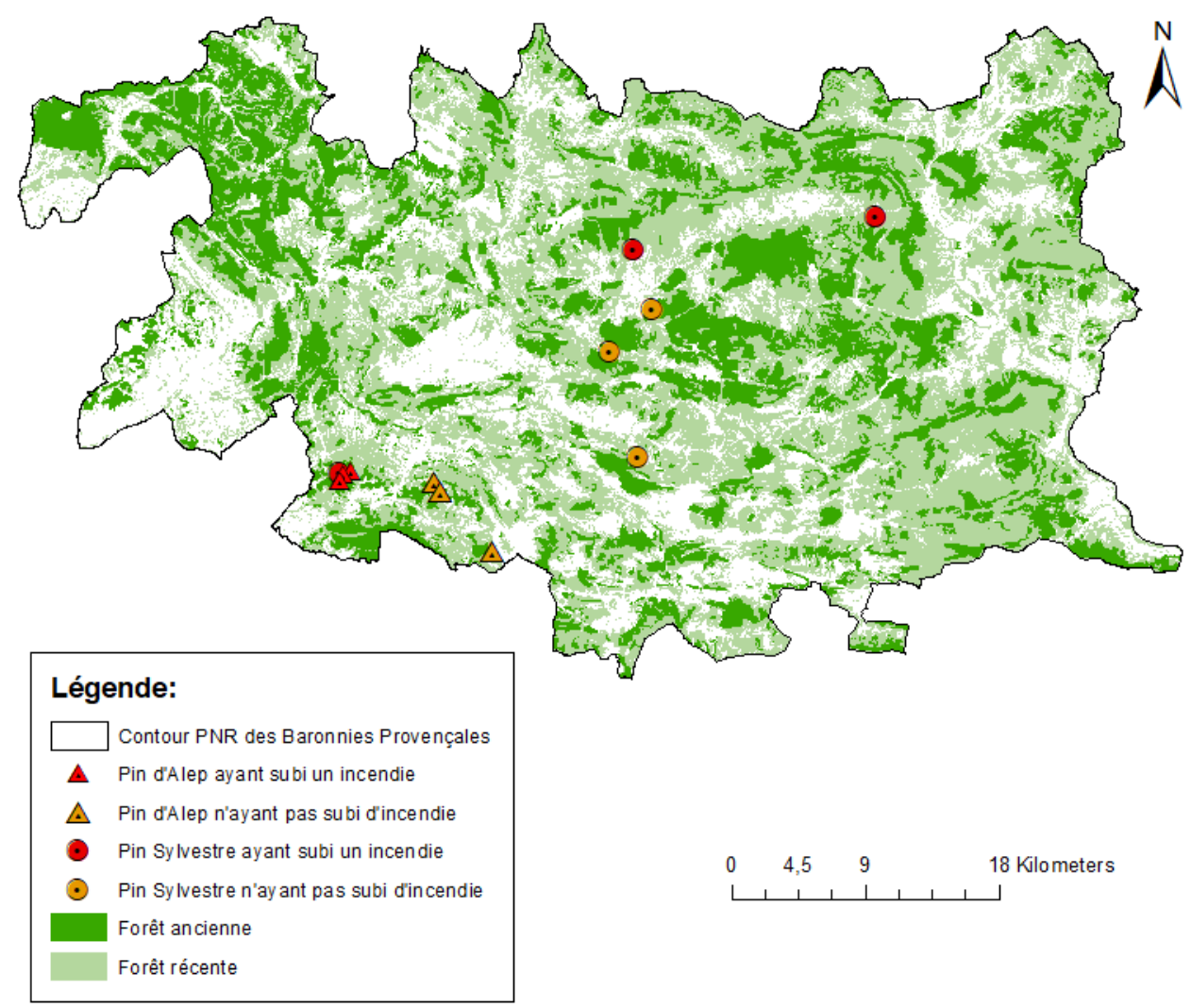

Figure 2 - Map of old forests (1850, dark green) and young forests (2014, light green) with site locations in Regional Natural Park of Baronnies Provençales (triangle: P. halepensis, circle: P. sylvestris and red: HiF, orange: NoF) 


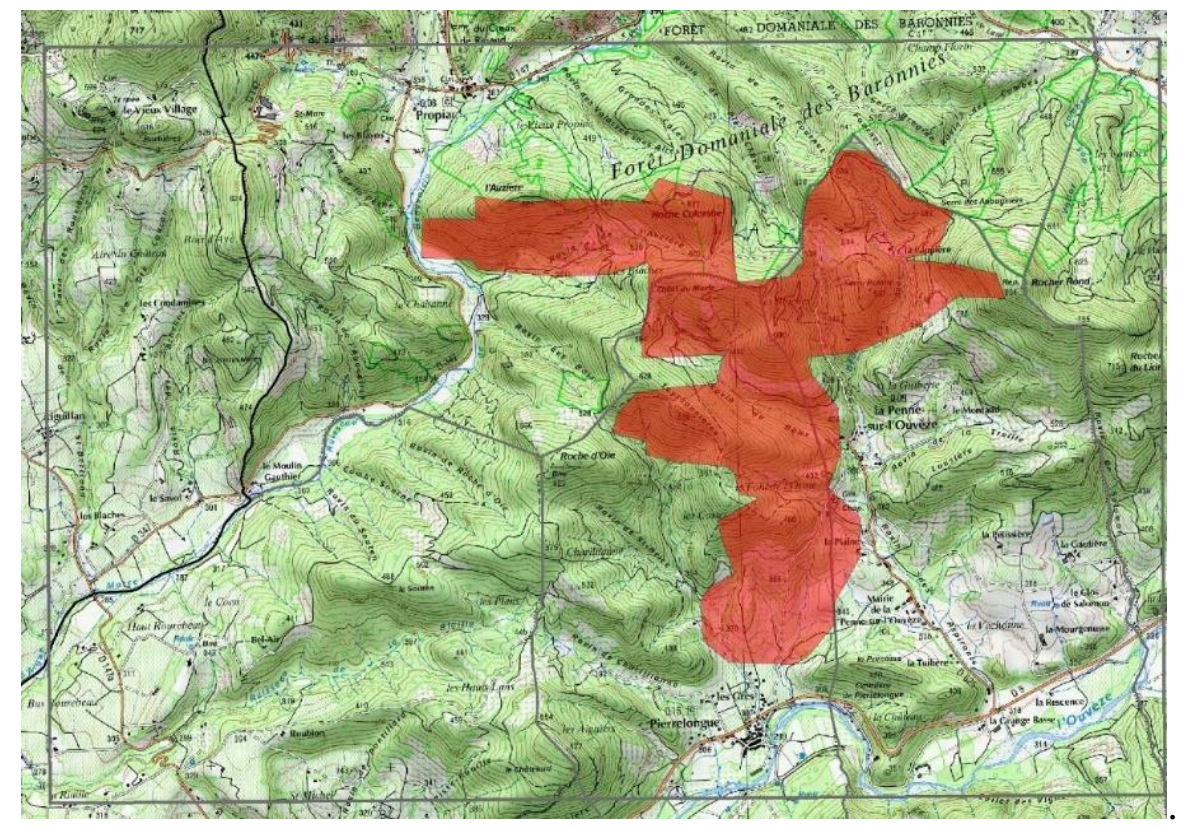

Figure 3 - Map of a fire that occurred in 1986 in Buis-les-Baronnies (Regional Natural Park of Baronnies Provençales, France)

\subsection{Fire-related traits measured}

The fire related traits taken into account in this work are functional, structural or chemical but depend on the species studied and on the adaptation strategy to fire. They are measured on 10 trees per populations.

Functional trait:

- Serotiny: based on Budde et al. (2014) the percentage of serotinous cones will be estimated using 300 cones per populations (10 for each tree sampled), these cones being located on two opposite branches. Serotiny will be assessed during summer to avoid counting errors as cones tend to remained closed in winter when the relative humidity is higher.

Structural traits:

- Bark thickness: for each individual, four measurements were carried out using a drill and a steel ruler.

- Self-pruning: height of the first branch.

- Branch bulk density (weight-to-volume ratio of the branch)

- Needle physical characteristics: for each tree sampled, 10 needles are selected randomly and their weight, volume, surface, surface to volume ratio (Hachmi et al. 2011), length are measured.

Chemical traits:

The terpene content is often studied in the assessment of flammability because of their low flash point (Owens et al. 1998; Alessio et al. 2008; Pausas et al. 2016). In this work, monoterpenes, sesquiterpenes, and diterpenes are analyzed (molecule diversity and concentration).

\subsection{Flammability assessment}

According to Anderson (1970) and Martin et al. (1993), flammability is defined by four components, i) ignitability (fuel capacity to ignite), ii) sustainability (how well the fuel continues to burn), iii) combustibility (how rapidly or intensely a material burns), and iv) consumability (amount of fuel that is consumed). In this study, we assess branch and litter flammability with adapted protocols for each species derived from previous works (Ganteaume et al. 2011, 2014). 


\subsubsection{Dead surface fuel flammability}

Two different protocols are used depending on the species but in each case, we used only pure pine litter demanding a time-consuming sorting of the litter samples collected in the field which contained different types of particles of different species. Regarding P. halepensis, $20 \mathrm{~g}$ of litter (3 burnings per tree) are burned in a circular aluminum tray placed on a weighing scale (Mettler Toledo scale with an accuracy of 0.01 g.) in order to record the mass loss during the burning (Fig. 4). Four thermocouples (k-thermocouples Omega, $25 \mathrm{~mm}$ ) are placed $10 \mathrm{~cm}$ above the sample centre for recording the temperature variation (Mean temperature, Maximal Temperature) during the burning. Just after the ignition (the ignition source is a flaming calibrated firebrand placed at the centre of the sample), timeto-ignition, rate of spread, flaming duration are recorded with a chronometer.

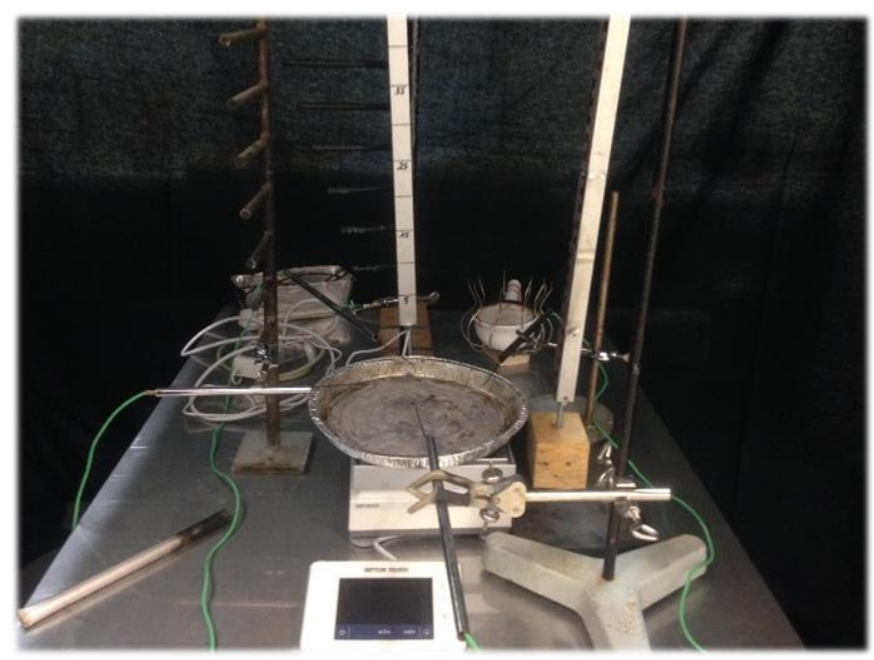

Figure 4 - P. halepensis' litter burning device.

Regarding $P$. sylvestris, 1g-needle samples are burned using an epiradiator as the amount of litter found under the trees was very low and did not allow designing $20 \mathrm{~g}$-samples as for the previous species. Only time-to-ignition, ignition frequency, flaming duration and maximum (and mean) temperature are recorded using this device according to Ganteaume et al. (2013).

\subsubsection{Branch flammability}

Thirty calibrated fresh branches of each species are burned on the same fire bench as the one used for assessing $P$. halepensis ' litter flammability. The branches are ignited by a flame front generated by an excelsior fuel bed located $10 \mathrm{~cm}$ below the branch.

\subsection{Terpene analysis}

The content of the three main terpene classes (monoterpenes, sesquiterpenes, diterpenes) is screened in the llive and dead leaves of the two species studied. The analyses are conducted on $10 \mathrm{~g}$ samples using a GC-MS (GC System 7890B - Agilent Technologies®).

\subsection{Molecular genetics}

Population structure, genetic diversity, and gene flow are assessed using molecular markers. A test of the correlation between genetic patterns and fire-related traits among populations focusing on serotiny is used to address the evolution of this trait. Microsatellites, or simple sequence repeats (SSRs), are regions the genome that contain short repeated stretches of nucleotides. Their high mutation rate, thought to result primarily from slippage during DNA replication, is extremely useful for measuring differences among populations. 


\section{Acknowledgements}

This work is funded by an European Feder programme POIA \#PA0005333.

\section{Reference}

Agee JK (1998) The landscape ecology of western forest fire regimes Northwest Science 72:24

Alessio G, Peñuelas J, Llusià J, Ogaya R, Estiarte M, De Lillis M (2008) Influence of water and terpenes on flammability in some dominant Mediterranean species International Journal of Wildland Fire 17:274-286

Anderson H (1970) Forest fuel ignitibility Fire technology 6:312-319

Behm AL, Duryea ML, Long AJ, Zipperer WC (2004) Flammability of native understory species in pine flatwood and hardwood hammock ecosystems and implications for the wildland-urban interface International Journal of Wildland Fire 13:355-365

Bond W, Van Wilgen B (1996) Fire and Plants (population and community biology series 14) Population and Community Biology 263

Bradshaw SD, Dixon KW, Hopper SD, Lambers H, Turner SR (2011) Little evidence for fire-adapted plant traits in Mediterranean climate regions Trends in plant science 16:69-76

Budde KB, Heuertz M, Hernández-Serrano A, Pausas JG, Vendramin GG, Verdú M, GonzálezMartínez SC (2014) In situ genetic association for serotiny, a fire-related trait, in Mediterranean maritime pine (Pinus pinaster) New Phytologist 201:230-241

Cowan PD, Ackerly DD (2010) Post-fire regeneration strategies and flammability traits of California chaparral shrubs International Journal of Wildland Fire 19:984-989

Frejaville T (2015) Vulnérabilité des forêts de montagne des Alpes occidentales au changement de régime d'incendie. Aix-Marseille

Ganteaume A, Jappiot M, Lampin C, Curt T, Borgniet L (2014) Flammability of litter sampled according to two different methods: comparison of results in laboratory experiments. International Journal of Wildland Fire 23, 1061-1075

Ganteaume A, Jappiot M, Lampin C (2013) Assessing the flammability of surface fuels beneath ornamental vegetation in wildland-urban interfaces in Provence (south-eastern France) International journal of wildland fire 22:333-342.

Ganteaume A, Jappiot M, Lampin-Maillet C, Curt T, Borgniet L (2011) Effects of vegetation type and fire regime on flammability of undisturbed litters in Southeastern France. Forest Ecology and Management 261, 2223-2231

Hachmi M, Sesbou A, Benjelloun H, Bouanane F (2011) Alternative equations to estimate the surfaceto-volume ratio of different forest fuel particles International Journal of Wildland Fire 20:648-656

Keeley JE (2012) Ecology and evolution of pine life histories Annals of Forest Science 69:445-453

Keeley JE, Pausas JG, Rundel PW, Bond WJ, Bradstock RA (2011) Fire as an evolutionary pressure shaping plant traits Trends in plant science 16:406-411

Kerr B, Schwilk DW, Bergman A, Feldman MW (1999) Rekindling an old flame: a haploid model for the evolution and impact of flammability in resprouting plants Evolutionary Ecology Research $1: 807-833$

Lamont BB, Le Maitre D, Cowling R, Enright N (1991) Canopy seed storage in woody plants The Botanical Review 57:277-317

Martin R et al. Assessing the flammability of domestic and wildland vegetation. In: Proceedings of the 12th conference on fire and forest meteorology, 1993. pp 26-28 
Moreno JM, Oechel WC (2012) The role of fire in Mediterranean-type ecosystems vol 107. Springer Science \& Business Media,

Moritz MA, Parisien M-A, Batllori E, Krawchuk MA, Van Dorn J, Ganz DJ, Hayhoe K (2012) Climate change and disruptions to global fire activity Ecosphere 3:1-22

Ne'eman G, Goubitz S, Nathan R (2004) Reproductive traits of Pinus halepensis in the light of fire-a critical review Plant Ecology 171:69-79

Oliveira S, Oehler F, San-Miguel-Ayanz J, Camia A, Pereira JM (2012) Modeling spatial patterns of fire occurrence in Mediterranean Europe using Multiple Regression and Random Forest Forest Ecology and Management 275:117-129

Owens MK, Lin C-D, Taylor CA, Whisenant SG (1998) Seasonal patterns of plant flammability and monoterpenoid content in Juniperus ashei Journal of Chemical Ecology 24:2115-2129

Papió C, Trabaud L (1991) Comparative study of the aerial structure of five shrubs of Mediterranean shrublands Forest Science 37:146-159

Pausas J, Alessio G, Moreira B, Segarra-Moragues J (2016) Secondary compounds enhance flammability in a Mediterranean plant Oecologia 180:103-110

Pausas JG (2004) Changes in fire and climate in the eastern Iberian Peninsula (Mediterranean basin) Climatic change 63:337-350

Pausas JG (2015) Bark thickness and fire regime Functional Ecology 29:315-327

Pausas JG, Alessio GA, Moreira B, Corcobado G (2012) Fires enhance flammability in Ulex parviflorus New Phytologist 193:18-23

Pausas JG, Keeley JE (2009) A burning story: the role of fire in the history of life BioScience 59:593601

Pausas JG, Keeley JE (2014) Evolutionary ecology of resprouting and seeding in fire-prone ecosystems New Phytologist 204:55-65

Retana J, Maria Espelta J, Habrouk A, Luis OrdoÑEz J, de Solà-Morales F (2002) Regeneration patterns of three Mediterranean pines and forest changes after a large wildfire in northeastern Spain Ecoscience 9:89-97

Santana VM, Baeza MJ, Vallejo VR (2011) Fuel structural traits modulating soil temperatures in different species patches of Mediterranean Basin shrublands International Journal of Wildland Fire 20:668-677

Saura-Mas S, Paula S, Pausas J, Lloret F (2010) Fuel loading and flammability in the Mediterranean Basin woody species with different post-fire regenerative strategies International Journal of Wildland Fire 19:783-794

Schwilk DW, Ackerly DD (2001) Flammability and serotiny as strategies: correlated evolution in pines Oikos 94:326-336

Schwilk DW, Caprio AC (2011) Scaling from leaf traits to fire behaviour: community composition predicts fire severity in a temperate forest Journal of Ecology 99:970-980

Schwilk DW, Kerr B (2002) Genetic niche-hiking: an alternative explanation for the evolution of flammability Oikos 99:431-442

Tapias R, Climent J, Pardos JA, Gil L (2004) Life histories of Mediterranean pines Plant ecology 171:53-68

Verdú M, Pausas JG, Segarra-Moragues JG, Ojeda F (2007) Burning phylogenies: fire, molecular evolutionary rates, and diversification Evolution 61:2195-2204

Westerling AL, Hidalgo HG, Cayan DR, Swetnam TW (2006) Warming and earlier spring increase western US forest wildfire activity science 313:940-943 